\title{
PENGUATAN UPAYA PENEGAKAN HUKUM "KEJAHATAN TERKAIT DENGAN PERIKANAN" MELALUI REGIONAL COOPERATION AGREEMENT AGAINST CRIMES RELATED TO FISHERIES
}

\author{
Ayu Mawar Rini* \\ Hukum Internasional, Fakultas Hukum, Universitas Gadjah Mada \\ Jalan Sosio Yustisia Nomor 1, Bulaksumur, Kabupaten Sleman, Daerah Istimewa Yogyakarta, 55281

\begin{abstract}
The research aims to analyse the urgency of the establishment of the Regional Cooperation Agreement Against Crimes Related to Fisheries. Considering the broad and emerging nature of Crimes Related to Fisheries, however, could not be solved accordingly by finding the recognition of IUUF as the form of Transnational Organized Crime. The initiative on establishing such agreement with the regional and market approach is trusted as the first practical solution taken by Indonesia to reduce the existence of Crimes Related to Fisheries, which at the same time strengthening the law enforcement for such crimes within the region.
\end{abstract}

Keywords: Crimes Related to Fisheries, Transnational Organized Crime, Regional Cooperation Agreement.

\section{Intisari}

Penelitian ini bertujuan untuk menganalisa urgensi pembentukan "Perjanjian Kerjasama Regional Melawan Kejahatan Terkait dengan Perikanan". Sifat "Kejahatan Terkait dengan Perikanan" yang luas serta terus berkembang tidak dapat serta merta diatasi dengan pengategorian IUUF sebagai bentuk dari Transnational Organized Crime. Inisiatif pembentukan perjnajian kerjasama dengan basis pendekatan kawasan dan pendekatan kawasan dipercaya mampu menjadi langkah awal bagi Indonesia serta menguatkan penegakan hukum untuk mengurangi kejahatan terkait di kawasan regional.

Kata Kunci: Kejahatan Terkait dengan Perikanan, Kejahatan Transnasional Terorganisasi, Perjanjian Kerjasama Regional.

\section{Pokok Muatan}

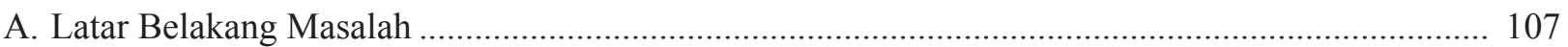

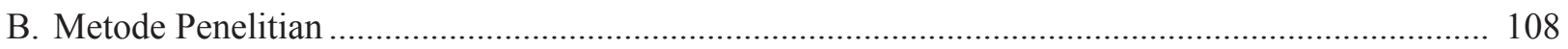

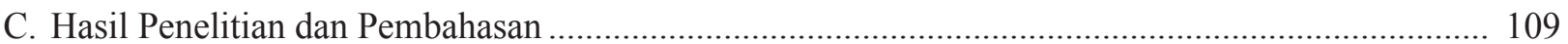

1. Urgensi Pembentukan Perjanjian Kerjasama Regional Melawan "Kejahatan Terkait dengan Perikanan" (Regional Cooperation Agreement Against Crimes Related to Fisheries) dalam Penguatan Upaya Penegakan Hukum Terhadap "Kejahatan Terkait dengan Perikanan".

2. Pengaruh Regional Cooperation Agreement against Crimes Related to Fisheries terhadap penguatan penegakan hukum maritim di Indonesia

3. Langkah-Langkah yang Dapat Dikontribusikan Indonesia dalam Rangka Mendorong Terbentuknya Perjanjian Kerjasama Regional Melawan "Kejahatan Terkait dengan Perikanan" (Regional Cooperation Agreement Against Crimes Related to Fisheries) .....

D. Kesimpulan

Korespondensi Penulis: ayu.mawar.r@mail.ugm.ac.id. 


\section{A. Latar Belakang Masalah}

Poros Maritim Dunia adalah suatu visi Indonesia untuk menjadi sebuah negara maritim yang berdaulat, maju, mandiri, kuat, serta mampu memberikan kontribusi positif bagi keamanan dan perdamaian kawasan dan dunia sesuai dengan kepentingan nasional. Visi Indonesia ini semakin diperkuat dengan kelahiran Peraturan Presiden Nomor 16 Tahun 2017 tentang Kebijakan Kelautan Indonesia. ${ }^{1}$

Besarnya produksi ikan yang terkandung dalam laut Indonesia seringkali menarik perhatian kapal-kapal penangkap ikan dari negara lain untuk membentangkan jaringnya di wilayah perairan Indonesia. Oleh karenanya, Indonesia sering menjadi target oleh para pelaku kejahatan perikanan dalam aktivitas Illegal, Unreported, Unregulated Fishing (selanjutnya disebut sebagai IUUF) di perairan Indonesia. Telah diperkirakan Indonesia pernah mengalami kerugian mencapai 2000 triliun rupiah hingga kurun waktu 2018 akibat praktik IUUF. ${ }^{2}$ Kurangnya pengawasan oleh aparat penegak hukum tersebut justru semakin membuka ruang bagi praktik IUUF di Indonesia.

IUUF yang terjadi di wilayah perairan Indonesia dinilai sebagai sebuah kejahatan yang terus berkembang, mengingat dalam praktiknya kejahatan IUUF seringkali terkait dengan kejahatan serius lainnya yang turut memanfaatkan status izin kapal penangkap ikan. Kejahatan-kejahatan tersebut bersifat transnasional dan terorganisir serta sebagian besar dinilai termasuk kedalam kategori tindak pidana serius (selanjutnya disebut dengan "Kejahatan Terkait dengan Perikanan"). Penggunaan terminologi "Kejahatan Terkait dengan Perikanan" dimaksudkan untuk membedakan tindak pidana yang telah resmi dikategorikan dalam Undang-Undang Nomor 45 Tahun 2009 Tentang
Perubahan Atas Undang-Undang Nomor 31 Tahun 2004 Tentang Perikanan (selanjutnya disebut dengan UU Perikanan). Hal ini dikarenakan dalam praktik, para pelaku IUUF tidak hanya melanggar UU Perikanan namun dalam beberapa kasus serius yang terjadi, para pelaku melanggar pula kejahatan lain yang belum dikategorikan oleh UU Perikanan. "Kejahatan Terkait dengan Perikanan" dapat meliputi penyelundupan satwa langka, penyelundupan narkoba, kerja paksa, dan penjualan manusia yang menggunakan kedok izin kapal penangkap ikan baik turut melakukan aktivitas perikanan ataupun tidak. Keseluruhan kejahatankejahatan tersebut nyatanya dikelola oleh sebuah organisasi yang terorganisir di beberapa negara selain di Indonesia.

Aktivitas "Kejahatan Terkait dengan Perikanan" di Indonesia seringkali tersorot perhatian publik secara pasang surut. Sayangnya, meskipun "Kejahatan Terkait dengan Perikanan" secara nyata terjadi di lautan Indonesia, pemerintah belum dapat menganalisa pola kejahatan yang terorganisasi dengan memberlakukan sanksi tegas bagi para pelaku kejahatan ini. Beberapa kasus nyata yang terjadi di Indonesia yang terlihat jelas bukti keberadaaan "Kejahatan Terkait dengan Perikanan" dapat dilihat dalam kasus Benjina di tahun 2015 dan Kasus MV. Sunrise Glory di tahun 2018.

Kasus Benjina tahun 2015 adalah salah satu contoh kasus tindak pidana perdagangan orang dan perbudakan manusia dibalik kegiatan IUUF. ${ }^{3}$ Terkuaknya tindak pidana ini justru didapati oleh Tim Satuan Tugas Pemberantasan Illegal Fishing (Satgas 115) yang menemukan 322 anak buah kapal (ABK) asing terdampar di areal pabrik milik PT Pusaka Benjina Resources (PBR) di Benjina, Kepulauan Aru, Maluku dengan kondisi yang sangat memprihatinkan. ${ }^{4}$

Pasal 1 Peraturan Peraturan Presiden Nomor 16 Tahun 2017 tentang Kebijakan Kelautan Indonesia (Lembaran Negara Republik Indonesia Tahun 2017 Nomor 32

CNBC Indoneisa, "Susi Akui RI Pernah Rugi Rp 2000 T Akibat Illegal Fishing”, https://www.cnbcindonesia.com/news/20180626075822-420458/susi-akui-ri-pernah-rugi-rp-2000-t-akibat-illegal-fishing, diakses Juni 2018.

BBC Indonesia, "Sidang kasus 'perbudakan' di Benjina digelar", http://www.bbc.com/indonesia/berita indonesia/2015/11/151118 indonesia_benjina_tual, diakses 3 Desember 2017.

4 Elisa Valenta Sari, CNN Indonesia, "Benjina, Kisah Perbudakan Ratusan Nelayan di Timur Indonesia”, https://www.cnnindonesia.com/ ekonomi/2015040 7155215-92-44823/benjina-kisah-perbudakan-ratusan-nelayan-di-timur-indonesia/, diakses 3 Desember 2017. 
Kasus nyata selanjutnya ialah kasus penyelundupan narkotika golongan I berjenis Sabu sebanyak 1 ton dengan nilai mencapai 1,5 triliun rupiah di sebuah kapal berbendera Singapura MV Sunrise Glory pada Maret 2018. Kapal Sunrise Glory adalah kapal berbendera Indonesia dengan dokumen kapal berasal dari Indonesia, namun ternyata telah ditemukan bukti bahwa kapal ini kerap berganti bendera kapal dan memalsukan dokumen kapal ketika memasuki wilayah hukum negara lain. Dokumen yang dimiliki juga merupakan dokumen fotokopi atau tanpa dokumen asli. Setelah pemeriksaan, Kapal Sunrise Glory yang berkedok kapal penangkap ikan, justru didalam kapal tidak ditemukan adanya satupun hasil tangkapan maupun alat tangkap ikan. ${ }^{5}$

Keberadaan "Kejahatan Terkait dengan Perikanan" di lautan Indonesia justru merupakan bukti hukum yang secara nyata belum mampu di tindak secara tegas serta bertentangan dengan visi Indonesia sebagai Poros Maritim Dunia yang selalu diperjuangkan oleh Indonesia. Sekuat apapun pemerintah memperbaiki aturan hukum nasional, apabila pemerintah tidak melihat pola "Kejahatan Terkait dengan Perikanan" sebagai Transnational Organized Crime serta tidak mengaplikasikan kerjasama penegakan hukum dengan negara lain tentunya kejahatan ini tidak akan pernah dapat diberantas secara tuntas. Hal ini dikarenakan "Kejahatan Terkait dengan Perikanan" tak hanya melibatkan negara pantai saja (Indonesia) namun juga negara tetangga dan negara bendera kapal. Dari segi investigasi kejahatan, suatu negara hanya bisa mengandalkan kerjasama dari perjanjian Mutual Legal Assistance baik secara multilalteral dan bilateral dengan negara lain. ${ }^{6}$

Perjuangan kerjasama internasional mulai digalakkan supaya dunia memberi perhatiannya kepada Indonesia dan memutuskan untuk membantu melindungi keamanan maritim dunia.
Penegakan hukum terhadap "Kejahatan Terkait dengan Perikanan" di Indonesia menjadi sangat menarik untuk dibahas. Upaya penegakan hukum di tingkat internasional yang kini tengah diperjuangkan Indonesia ialah melalui pembentukan Perjanjian Kerjasama Regional Melawan "Kejahatan Terkait dengan Perikanan" (Regional Cooperation Agreement Against Crimes Related to Fisheries).

Penelitian terdahulu banyak mengkaji mengenai IUUF beserta penegakannya. Penelitian ini merupakan penelitian baru yang pertama kali membahas mengenai Kejahatan Perikanan yang diupayakan melalui bentuk perjanjian kerjasama regional dan sepanjang pengetahuan Penulis, belum pernah diteliti sebelumnya, oleh sebab itu penelitian ini merupakan karya asli dari Penulis. Berdasarkan latar belakang tersebut adapun rumusan masalah yang diangkat yakni: Pertama, bagaimana urgensi Perjanjian Kerjasama Regional Melawan "Kejahatan Terkait dengan Perikanan" (Regional Cooperation Agreement Against Crimes Related to Fisheries) dalam menguatkan upaya penegakan hukum terhadap "Kejahatan Terkait dengan Perikanan"?; Kedua, bagaimana pengaruh Perjanjian Kerjasama Regional Melawan "Kejahatan Terkait dengan Perikanan" (Regional Cooperation Agreement Against Crimes Related to Fisheries) terhadap penguatan penegakan hukum maritim di Indonesia?; Ketiga, apa sajakah langkahlangkah yang dapat dikontribusikan Indonesia dalam rangka mendorong terbentuknya Perjanjian Kerjasama Regional Melawan "Kejahatan Terkait dengan Perikanan" (Regional Cooperation Agreement Against Crimes Related to Fisheries)?

\section{B. Metode Penelitian}

Penelitian ini adalah penelitian normatif eksplanatoris karena meneliti bahan pustaka atau data sekunder yang kemudian dianalisis dalam

Hadi Maulana, "1 Ton Sabu Disita dari Kapal Berbendera Singapura, Nilainya Capai Rp 1,5 T", https://regional.kompas.com/ read/2018/02/10/07120901/1-ton-sabu-disita-dari-kapal-berbendera-singapura-nilainya-capai-rp-15-t, diakses 7 Maret 2018.

Jan Glazewski, et al., "Introduction and Overview: Transnational Organised Fisheries Crime", Elsevier: Marine Policy, Vol. 105, July 2019, hlm. 119 . 
lingkup upaya penegakan hukum "Kejahatan Terkait dengan Perikanan" melalui Perjanjian Kerjasama Regional Melawan "Kejahatan Terkait dengan Perikanan" (Regional Cooperation Agreement Against Crimes Related to Fisheries).

Jenis data yang digunakan adalah data sekunder yang diperoleh melalui studi kepustakaan serta didukung oleh wawancara dengan narasumber dari Kementerian Luar Negeri Republik Indonesia pada 2018 yakni Dr. iur. Damos Dumoli Agusman, SH, M.A. selaku Direktur Jenderal Hukum dan Perjanjian Internasional, Indra Rosandry, S.H., LL.M. selaku Kasubdit Politik dan Kerjasama Penegakan Hukum Direktorat Hukum dan Perjanjian Politik dan Keamanan Kementerian Luar Negeri, dan Galuh Indriana Rarasanti, S.H., M.Kn selaku Staf Fungsional yang bertugas di bagian Direktorat Hukum Dan Perjanjian Kewilayahan, Sub Direktorat Kerjasama Kelautan.

Penelitian ini dilakukan di beberapa tempat yang terkait dalam topik penelitian yakni di Jakarta tepatnya di Kementerian Luar Negeri tepatnya Direktorat Hukum dan Perjanjian Politik dan Keamanan, dan di Yogyakarta tepatnya berlokasi di Fakultas Hukum Universitas Gadjah Mada.

Analisis yang dilakukan Penulis adalah analisis dengan pendekatan kualitatif, yang prinsip pokoknya adalah mengolah dan menganalisis datadata yang terkumpul menjadi data yang sistematik, teratur, terstruktur, dan mempunyai makna. Dalam proses analisis data, pendekatan yang digunakan Penulis ialah pendekatan undang-undang (statute approach). ${ }^{7}$ Pendekatan undang-undang ini dilakukan dengan menelaah semua regulasi yang bersangkut paut dengan isu hukum yang sedang ditangani $^{8}$
C. Hasil Penelitian dan Pembahasan

1. Urgensi Pembentukan Perjanjian Kerjasama Regional Melawan "Kejahatan Terkait dengan Perikanan" (Regional Cooperation Agreement Against Crimes Related to Fisheries) dalam Penguatan Upaya Penegakan Hukum Terhadap "Kejahatan Terkait dengan Perikanan"

Perkembangan "Kejahatan Terkait dengan Perikanan" yang terjadi di wilayah laut suatu negara tidak hanya melibatkan pelaku yang berasal dari negara pantai saja, namun juga melibatkan pelaku yang berasal dari negara lain', hal ini kemudian menjadikan "Kejahatan Terkait dengan Perikanan" sebagai Emerging Crimes. Kerjasama para kelompok kejahatan ini sifatnya terencana dan terorganisir dalam menjalankan praktik "Kejahatan Terkait dengan Perikanan" itu sendiri, akibatnya "Kejahatan Terkait dengan Perikanan" semakin identik dengan Transnational Organized Crime.

"Kejahatan Terkait dengan Perikanan" seringkali hadir dengan status dibawah izin penangkapan ikan, baik benar-benar melakukan praktik penangkapan ikan di Wilayah Pengelolaan Perikanan Negara Kesatuan Republik Indonesia (WPPNKRI), atau bisa saja hanya menggunakan izin penangkapan ikan sebagai izin beroperasi kapal tanpa melakukan penangkapan ikan sama sekali. "Kejahatan Terkait dengan Perikanan" seperti itulah yang kemudian dikatakan sebagai "Kejahatan Terkait dengan Perikanan" yang berada dibalik kedok IUUF.

Kemudian, hal yang perlu dicatat ialah bahwa beberapa IUUF dapat pula digerakkan oleh pelaku yang tidak menjadi bagian dari kelompok kejahatan terorganisir tertentu seperti salah satunya pejabat publik ataupun entitas yang justru secara "sah" diakui di suatu negara. Peran pelaku ini contohnya adalah untuk memalsukan dokumen untuk tujuan

Ariesto Hadi Sutopo, et al., 2010, Terampil Mengolah Data Kualitatif dengan NVIVO, Prenada Media Group, Jakarta, hlm. 27.

Peter Mahmud Marzuki, 2008, Penelitian Hukum, Kencana, Jakarta, hlm. 93.

Simela Victor Muhamad, "Illegal Fishing di Perairan Indonesia: Permasalahan dan Upaya Penanganannya Secara Bilateral Di Kawasan", Jurnal Politica, Vol. 3, No. 1, Mei 2012, hlm.59. 
memperlancar proses aktivitas IUUF. ${ }^{10}$ Contoh IUUF seperti ini yang tidak dapat dikategorikan sebagai transnational organized crime karena tidak memenuhi unsur Pasal 3 UNTOC.

Kasus Benjina dengan kapal berkebangsaan Thailand yang terjadi pada tahun 2015 lalu dan kasus Kapal MV Sunrise Glory berkebangsaan Singapura yang membawa 1 ton narkoba dibalik statusnya sebagai kapal penangkap ikan, mampu menjadi pedoman paling nyata untuk menjelaskan dimana letak IUUF, "Kejahatan Terkait dengan Perikanan" serta letak Transnational Organized Crime. Kasus MV Sunrise Glory dan Kasus Benjina secara nyata menunjukkan pada dunia internasional bahwa kejahatan telah berkembang dan peluang yang ada dimanfaatkan sedemikian rupa untuk terus terhindar dari jeratan hukum.

Pemerintah Indonesia melalui beberapa kementerian telah bekerja sama untuk dapat menetapkan "Kejahatan Terkait dengan Perikanan" sebagai bagian dari Transnational Organized Crime di tingkat internasional. Isu ini awalnya diupayakan melalui penetapan IUUF sebagai bentuk Transnational Organized Crime. ${ }^{I I}$ Berbagai penelitian ilmiah hingga konferensi internasional seperti United Nations Open-ended Informal Consultative Process on Oceans and the Law of the Sea (UNICPOLOS) dan Conference of Parties to the UN Convention against Transnational Organised Crime Tahun 2008 telah berusaha memberikan hubungan antara IUUF dan Transnational Organized Crime. ${ }^{12}$ Pengategorian IUUF tidak dapat sematamata dilakukan secara mudah mengingat rezim yang berbeda serta unsur Transnational Organized
Crime yang tidak secara absolut dimiliki disetiap kasus IUUF. 13

Perjuangan Indonesia dalam menetapkan IUUF sebagai Transnational Organized Crime pun banyak menimbulkan pertentangan di level internasional. Hal ini dikarenakan terdapat dua tujuan rezim yang berbeda yakni IUUF dan Transnational Organized Crime. IUUF merupakan rezim dari Food and Agriculture Organization (selanjutnya disebut sebagai FAO) sebagai isu manajemen sumber daya, sedangkan Transnational Organized Crime sebagai elemen penegakan hukum dibawah rezim United Nations Convention Against Transnational Organized Crime (selanjutnya disebut sebagai UNTOC). Meskipun keduanya tetap saling terkait di lapangan (contoh nyatanya ialah Kasus Benjina), namun tetap saja nyatanya banyak negara yang terus menentang penetapan tersebut. $^{14}$

Indonesia pada tahun 2009 sempat berusaha mengategorikan elemen IUUF sebagai Transnational Organized Crime melalui resolusi Transnational Organized Crime at Sea dalam forum United Nations Office on Drugs and Crime (selanjutnya disebut sebagai UNODC). ${ }^{15}$ Namun sayangnya upaya ini gagal karena secara mutlak ditolak oleh China, Vietnam, Spanyol, dan Korea Selatan dengan alasan bahwa pembahasan IUUF dalam forum UNODC bukanlah pilihan yang tepat karena IUUF sendiri merupakan isu manajemen yang dapat merujuk ke UNCLOS. Forum UNODC bukanlah forum untuk membahas UNCLOS, namun cakupan forum ialah UNTOC serta konvensikonvensi lain terkait dengan rezim crimes dan

10 Don Liddick, “The Dimensions of A Transnational Crime Problem: The Case of IUU Fishing”, Springer,Vol. 17, No. 4, Desember 2014, hlm. 297.

11 Elisabeth S. Puspoayu, et al., "Illegal, Unreported, and Unregulated Fishing as Transnational Organized Crimes", SHS Web Conferences, The 1st International Conference on Law, Governance and Social Justice, Vol. 54, 2018, hlm. 4.

12 United Nations, "Conference of Parties to the United Nations Convention Against Transnational Organized Crime, Report of the Conference of Parties to the United Nations Convention Against Transnational Organized Crime on its Fourth Session, Vienna, October 8-17, 2008", UNODC CTOC/COP/2008/19, 1 December 2008, para. 210.

13 INTERPOL Global Fisheries Enforcement, 2018, International Law Enforcement Cooperation in the Fisheries Sector: A Guide for Law Enforcement Practitioners, INTERPOL, hlm. 18

14 Damos Dumoli Agusman (Direktur Jenderal Hukum dan Perjanjian Internasional Kementerian Luar Negeri Republik Indonesia) wawancara pada 9 Februari 2018 di Gedung Rektorat Universitas Gadjah Mada, Yogyakarta.

15 Indra Rosandry (Kepala Sub Direktorat Hukum dan Perjanjian Politik dan Keamanan, Direktorat Jenderal Hukum dan Perjanjian Internasional Kementerian Luar Negeri Republik Indonesia) wawancara pada 12 April 2018 di Kementerian Luar Negeri Republik Indonesia, Jakarta. 
penegakan hukum. ${ }^{16}$

Penolakan yang terjadi terhadap dua rezim yang berbeda ini terfokus pada maksud tujuan pembentukan masing-masing organisasi dan ranah objek yang diatur didalamnya. Meskipun organisasi internasional digunakan untuk memfasilitasi kepentingan publik dalam misinya, namun tumpang tindih mandat setiap organisasi internasional (FAO dan UNODC) harus dihindari sejauh mungkin. ${ }^{17}$ Oleh sebab itu masing-masing tujuan, pengimplementasian serta sanksi yang berlaku akan disesuaikan sesuai koridor tujuan organisasi tersebut. Terlebih pembentukan masing-masing organisasi telah melewati proses historis yang dicapai kesepakatan oleh mayoritas negara di dunia. Penarikan hubungan antara satu jenis tindak pidana kedalam tindak pidana lain tentunya memerlukan persetujuan secara konsensus oleh setiap negara anggota setiap organisasi internasional.

Dampak besar yang mungkin terjadi apabila IUUF ditetapkan sebagai Transnational Organized Crime ialah perombakan hukum perikanan nasional dan internasional dari sanksi administratif menjadi sanksi pidana. $^{18}$ Sehingga, menanggapi IUUF melalui pendekatan "Kejahatan Terkait dengan Perikanan" dinilai dapat menjadi solusi dalam membingkai ulang masalah penangkapan ikan illegal beserta dengan 'kejahatan perikanan lain' dari masalah hukum administratif (karena IUUF dikonseptualisasikan dalam kerangka sanksi administratif), menjadi masalah hukum pidana. ${ }^{19}$

Ide suatu negara untuk penetapan kejahatan baru sebagai Transnational Organized Crime tidak dapat dijustifikasi sebagai hal yang salah ataupun benar secara kasat mata. UNTOC sendiri tidak membentuk konvensi dengan sistem dimana memaksa satu atau beberapa bentuk organisasi perilaku kirminal ke dalam satu definisi tunggal kejahatan terorganisir, ${ }^{20}$ selain beberapa tindak pidana utama yang disebutkan dalam UNTOC Pasal 2, 5, 6, 8, dan 23. Tidak adanya pengategorian kejahatan secara khusus bukanlah tanpa maksud. Hal ini ditujukan agar konvensi internasional dapat menjadi alat untuk dapat diaplikasikan secara luas ${ }^{21}$ serta mendorong berbagai ahli untuk menciptakan definisi yang lebih terstruktur dan merepresentasikan kejahatan kejahatan serius lain yang memiliki elemen lintas batas"2 . "Kejahatan Terkait dengan Perikanan" sendiri merupakan konsep baru yang mungkin tidak secara jelas tercakup dalam UNTOC ataupun protokolnya, namun tak ada alasan untuk mengecualikan tipe kejahatan ini dalam lingkup UNTOC. ${ }^{23}$

Seiring dengan perkembangan kerjasama internasional, organisasi internasional berusaha untuk terus mengaktualisasikan perjanjian internasional untuk dapat disesuaikan dengan kebutuhan penegakan hukum dunia internasional. Salah satunya ialah INTERPOL yang berusaha mengedukasi setiap negara anggota untuk lebih waspada terhadap bentuk baru kejahatan baik secara nasional maupun internasional dengan memberikan arahan tipe-tipe pelanggaran "Kejahatan Terkait dengan Perikanan" yang memasuki kategori Transnational Organized Crime. ${ }^{24}$

Perkembangan selanjutnya menunjukkan

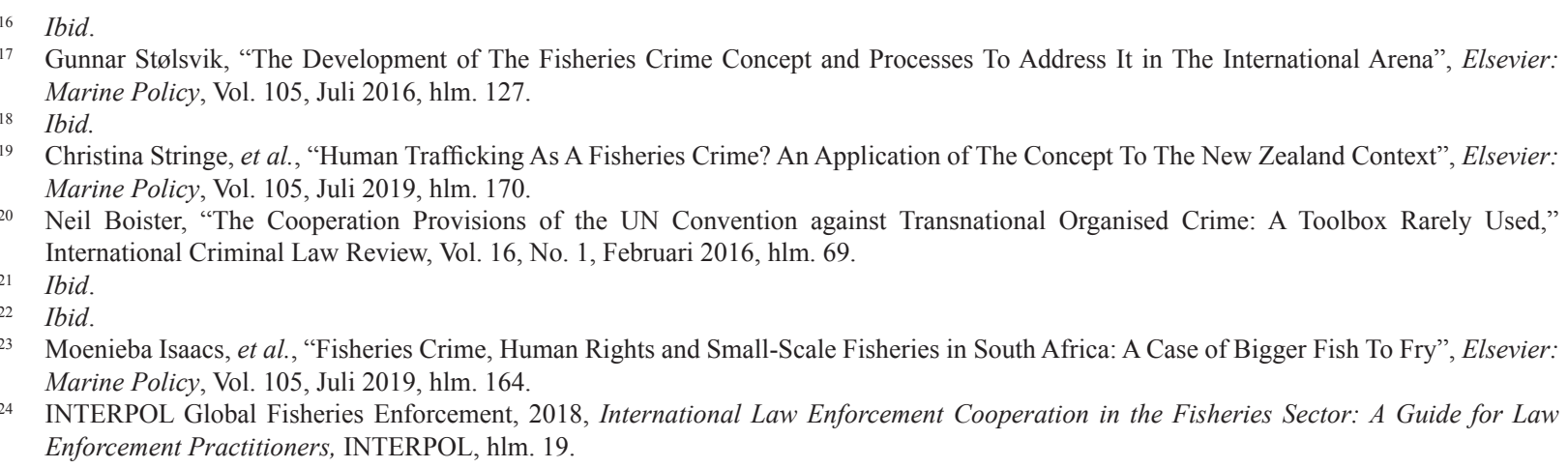


bahwa upaya Indonesia dalam menetapkan kejahatan di sektor perikanan sebagai Transnational Organized Crime, belum dapat menarik IUUF sebagai dasar tindak pidana. Negara-negara selain Indonesia menilai bahwa "Kejahatan Terkait dengan Perikanan" dinilai lebih dapat diterima untuk menjadi salah satu unsur dalam Transnational Organized Crime. Terlebih, pendekatan sempit terhadap kegitaan illegal di sektor perikanan dengan hanya berfokus pada aturan IUUF oleh suatu negara tidak akan memadai untuk memenuhi urgensi kejahatan perikanan yang semakin berkembang seiring perkembangan jaman. $^{25}$ Terutama di Indonesia, penegakan hukum untuk pelaku IUUF dengan target kriminal korporasi hanya dijatuhkan sanksi hukuman penjara atau denda "hanya" kepada manajemen perusahaan saja dan ini sendiri merupakan sebuah ketidakadilan. ${ }^{26}$

Penggunaan "Kejahatan Terkait dengan Perikanan" oleh karenanya lebih direkomendasikan, mengingat cakupan luas yang dimaksudkan dalam penggunaan terminologi tersebut dibanding dengan penggunaan tindak pidana di bidang perikanan yang seringkali disebut dengan IUUF. Meskipun begitu, perlu diperhatikan bahwa IUUF merupakan bagian daripada "Kejahatan Terkait dengan Perikanan" sehingga tanpa menggunakan dasar IUUF pun sesungguhnya IUUF tetap masih menjadi salah satu jenis kejahatan dalam "Kejahatan Terkait dengan Perikanan".

Perjalanan penetapan hukum bahwa "Kejahatan Terkait dengan Perikanan" adalah bagian protokol dalam UNTOC masih cukup panjang. Oleh sebab itu Indonesia tetap harus terus memberikan pressure terhadap kejahatan yang mungkin akan terjadi serta meminimalisir pergerakan kejahatan seminimal mungkin, salah satunya melalui konvensi regional yang lebih komprehensif dalam lingkup "Kejahatan Terkait dengan Perikanan" yang akan memberikan komitmen lebih kuat daripada kerja sama bilateral sebelumnya. ${ }^{27}$

Bentuk nyata dari hasil upaya diplomasi dimaksud dapat tercermin dari inisiatif yang telah didorong oleh Indonesia melalui beberapa konferensi seperti UN Congress Crime Prevention and Criminal Justice di Doha bulan April 2015 dan di Wina bulan Mei 2016, untuk menyampaikan pentingnya perhatian serius negara-negara terhadap kejahatan perikanan dan kejahatan yang terkait dengan perikanan dan mengharapkan agar kejahatan tersebut diperlakukan dalam keranjang yang sama seperti manifestasi-manifestasi lain dari Transnational Organized Crime. ${ }^{28}$

Mengenai Transnational Organized Crime dan "Kejahatan Terkait dengan Perikanan", pada kancah regional, Indonesia menyambut baik komitmen yang dibuat oleh negara-negara anggota The Indian Ocean RIM Association: Promoting Regional Cooperation for a Peaceful, Stable and Prosperous Indian Ocean atau IORA sebagaimana tercantum dalam Jakarta Concord pada tahun 2017. Kerjasama ini bertujuan untuk mempromosikan keamanan dan keamanan maritim di wilayah tersebut, antara lain memperkuat kerja sama regional untuk mengatasi tantangan lintas batas, termasuk pembajakan, perampokan bersenjata di laut, terorisme, perdagangan orang, penyelundupan manusia, perdagangan manusia, perdagangan gelap narkoba, perdagangan gelap satwa liar, kejahatan di sektor perikanan, dan kejahatan lingkungan. ${ }^{29}$

Pemerintah Indonesia tengah memperjuang-

\footnotetext{
25 Jan Glazewski, "Legal and Practical Challenges Around Restitution, Secrecy and Asset Recovery in Transnational Fisheries Crime: A Case Study of United States v Bengis, 2013", Elsevier: Marine Policy, Vol. 105, July 2019, hlm. 156.

26 Sri Dewi RN., et al., "Corporation As The Actors of Fisheries Crime in Indonesia", Jurnal Dinamika Hukum, Vol. 18, No. 2, May 2018, hlm. 210.

27 Indra Rosandry (Kepala Sub Direktorat Hukum dan Perjanjian Politik dan Keamanan, Direktorat Jenderal Hukum dan Perjanjian Internasional Kementerian Luar Negeri Republik Indonesia) wawancara pada 12 April 2018 di Kementerian Luar Negeri Republik Indonesia, Jakarta.

28 INTERPOL Global Fisheries Enforcement, 2018, International Law Enforcement Cooperation in the Fisheries Sector: A Guide for Law Enforcement Practitioners, INTERPOL, hlm. 19.

29 Aryuni Yuliantiningsih, et al., "From Illegal, Unreported and Unregulated Fishing to Transnational Organised Crime in Fishery from an Indonesian Perspective", Journal of East Asia and International Law, Vol. 11, No. 2, November 2018, hlm. 353.
} 
kan kelahiran sebuah kerjasama di kawasan regional dengan tujuan utama mencegah dan memberantas "Kejahatan Terkait dengan Perikanan" di kawasan regional maupun di negara-negara pasar ikan global (global fish market countries). Kerjasama regional ini nantinya akan diberi nama, Regional Cooperation Agreement against Crimes Related to Fisheries, atau Perjanjian Kerjasama Regional Melawan "Kejahatan Terkait dengan Perikanan". Perjanjian ini nantinya akan bersifat legally binding atau mengikat secara hukum bagi Negara Pihak yang terikat didalamnya.

Hal ini tentunya akan menjadi perwujudan visi Indonesia sebagai Poros Maritim Dunia dan misi Indonesia seturut dengan tujuan Pembangunan Berkelanjutan atau Sustainable Development Goal Perserikatan Bangsa-Bangsa nomor $14 .{ }^{30}$ Strategi yang digunakan dalam mewujudkan pendekatan tersebut ialah dengan menggerakkan aktor-aktor yang berperan dalam menegakkan "Kejahatan Terkait dengan Perikanan" yakni seperti flag states, coastal states, port states, markets, dan entitas penangkap ikan. Para aktor harus bergerak bersama dalam satu lingkup kerjasama kooperatif berdasarkan instrumen hukum yang mengikat.

Inisiasi kerjasama regional ini dinilai akan lebih memiliki efek signifikan bagi pemberantasan "Kejahatan Terkait dengan Perikanan". Salah satu bukti nyata keberhasilan penegakan hukum melalui perjanjian kerjasama regional adalah The Malacca Strait Patrols. ${ }^{31}$ Kerjasama ini adalah bukti nyata hasil kerjasama antara Malaysia, Singapura, Thailand dan Indonesia dalam penekanan angka pembajakan kapal di Selat Malaka ${ }^{32}$ melalui Joint Coordinated Patrol ${ }^{33}$ di wilayah perairan masingmasing negara dengan menetapkan beberapa titik-titik pengawasan dan melaksanakan patrol terkoordinasi tanpa memasuki perairan negara lain.

Rasionalisasi pentingnya perjanjian kerjasama ini selanjutnya ialah bahwa keberadaan "Kejahatan Terkait dengan Perikanan" dengan keterlibatan kelompok penjahat terorganisasi lintas negara membuat aparat penegak hukum nasional kesulitan untuk dapat mengusut kelompok terorganisasi di wilayah negara lain $^{34}$, meskipun kerjasama bilateral telah terbentuk. Terutama kenyataan bahwa pejabat publik yang mungkin terlibat juga menambah sulitnya investigasi ${ }^{35}$ hingga ke akar permasalahan. Oleh sebab itu, penanganan secara efektif "Kejahatan Terkait dengan Perikanan" membutuhkan tingkat koordinasi dan kerjasama yang tinggi secara lintas batas negara terutama dalam hal investigasi, seperti pembagian informasi antar institusi di bidang hukum, maritim, pajak, kepabeanan, maupun pelabuhan. ${ }^{36}$ Permasalahan ini dapat ditekan melalui aktualisasi kerjasama melalui Regional Cooperation Agreement against Crimes Related to Fisheries.

30 United Nations, "Transforming our world: the 2030 Agenda for Sustainable Development", Resolution adopted by the General Assembly, A/ RES/70/1, 25 September 2015, Goal, hlm. 14.

31 Catherine Zara Raymond, "Piracy and Armed Robbery in The Malacca Strait", Naval War College Review, Vol. 62, No. 3, , Summer 2009, hlm. 32 .

"While piracy has certainly been a concern in the water- way in the past, with reported attacks reaching seventy-five in 2000 , the number of cases has been falling since 2005, largely as a result of a number of counter- measures introduced by the three littoral states of Malaysia, Singapore, Thailand and Indonesia. This decrease in attacks was achieved despite a 10 percent increase in cases worldwide."

32 Ada Suk Fung Ng, 2011, A Maritime Security Framework for Fighting Piracy, Institute Of Transport And Logistics Studies, Working Paper ITLS-WP-11-21, The Australian Key Centre in Transport And Logistics Management, The University Of Sydney, Australia.

33 Direktorat Hukum dan Perjanjian Politik dan Keamanan Kementerian Luar Negeri, "Evaluasi Nawacita Pemerintahan Jokowi di Bidang Kerja Sama Maritim" Aspek Illegal, Unreported, and Unregulated Fishing (IUUF) dan Kejahatan Transnasional Terorganisasi di Sektor Perikanan, Seminar Direktur Jenderal Hukum dan Perjanjian Internasional Kementerian Luar Negeri, Kementerian Luar Negeri Republik Indonsia, Jakarta, 2017.

"Joint Air Patrols yang bernama The Eyes-in-the-Sky (EiS) menyediakan pengawasan udara gabungan dan terkoordinasi dari Selat Singapura dan Malaka. ... dilakukan pada wilayah perairan dan jurisdiksi masing-masing negara; dan dilakukan dengan negara yang berbatasan secara langsung"

34 Don Liddick, “The Dimensions of A Transnational Crime Problem: The Case of IUU Fishing”, Springer, Vol. 17, No.4, Desember 2014, 300. Ibid, 297.

36 Jan Glazewski, et al., "Introduction and Overview: Transnational Organised Fisheries Crime", Elsevier: Marine Policy, Vol. 105, July 2019, hlm. 119 . 
Indonesia telah menginisiasi beberapa bentuk pertemuan dalam pembentukan Regional Cooperation Agreement against Crimes Related to Fisheries yang turut pula dihadiri oleh organisasiorganisasi internasional terkait seperti FAO, UNODC, dan Interpol. Proses pembentukan kerjasama regional tersebut telah diinisiasi melalui beberapa pertemuan yakni:

a. Regional Conference to Establish a Regional Convention Against IUUF and Its Related Crimes tanggal $19 \mathrm{Mei}$ 2016 di Bali

Pada konferensi pertama ini, Indonesia menyatakan inisiatifnya untuk membentuk sebuah konvensi regional dalam rangka memerangi IUUF dan kejahatan terkait (Regional Convention on Combating IUUF and Its Related Crimes). Konferensi ini dihadiri oleh negara-negara yang memiliki perairan di kawasan ASEAN dan perairan sekitarnya yaitu Australia, Selandia Baru, Timor Leste, PNG, China dan negara-negara pasar ikan dunia yakni Amerika Serikat, Uni Eropa, dan Korea, serta organisasi internasional FAO dan UNODC serta West African SFRC. ${ }^{37}$

b. $\quad \quad^{\text {st }}$ Technical Experts' Meeting of the Conference tanggal 2-3 Mei 2017 di Surabaya

Terdapat beberapa masukan dari beberapa negara pada pertemuan ini, dengan kesepakatan untuk mengalihkan topik diskusi dari isu pokok IUUF and Its Related Crimes menjadi Crimes Related to Fisheries atau "Kejahatan Terkait dengan Perikanan". Perubahan pendekatan ini mempertimbangkan concern beberapa negara selama proses diskusi, dengan lebih memusatkan kepada rangkaian kejahatan terkait industri perikanan. Hadirnya pendekatan baru mengenai apa sebenarnya yang ingin ditarget oleh internasional, yakni "Kejahatan Terkait dengan Perikanan" dalam lingkup perkembangan kejahatan baru didalam naungan Transnational Organized Crime bukan tanpa alasan. Hal ini dikarenakan target yang ingin diberantas bukanlah semata-mata hanya IUUF namun sebenarnya adalah kejahatan lain yang berada dibalik IUUF tersebut.

c. The $3^{\text {rd }}$ Regional Conference on the Establishment of a Regional Cooperation Agreement against Crimes Related to Fisheries tanggal 18-19 September 2017 di Jakarta

Konferensi ini sepakat untuk membentuk Technical Working Group dengan mandat antara lain melakukan analisis terkait konsep IUUF dan crimes related to fisheries serta mulai membahas kemungkinan disusunnya sebuah instrumen yang mengikat dalam melawan kejahatan terkait perikanan. Mengingat adanya perubahan pendekatan dari Indonesia berdasarkan masukan negaranegara peserta pada konferensi sebelumnya, fokus pembahasan kini beralih pada pembentukan perjanjian kerja sama regional melawan kejahatan terkait perikanan.

Negara peserta membahas pandangan dan pengalaman negara peserta dan organisasi internasional dalam memerangi "Kejahatan Terkait dengan Perikanan". Oleh karena telah terdapat persamaan pandangan bahwa perlu adanya pemisahan yang jelas antara penanganan IUUF yang merupakan isu manajemen dan konservasi perikanan, dengan penanganan kejahatan transnasional terorganisir dalam industri perikanan yang merupakan isu penegakan hukum, maka diharapkan Technical Working Group dapat

Kementerian Koordinator Bidang Kemaritiman, "Menjajaki Pembentukan Konvensi Regional Tentang IUUF”, https://maritim.go.id/ menjajaki-pembentukan-konvensi-regional-tentang-iuuf/, diakses 2 Juni 2018. 
membahas upaya realistis untuk dapat mengakomodasi permasalahan "Kejahatan Terkait dengan Perikanan" secara tepat dan efektif. $^{38}$

d. $\quad 1^{\text {st }}$ Technical Working Group tanggal 20-21 Maret 2018 di Jakarta

Technical Working Group ini telah melaksanakan pertemuan pertama di Jakarta tanggal 20-21 Maret 2018. $1^{\text {st }}$ Technical Working Group pun telah membahas mengenai modalitas dan substansi perjanjian kerjasama.

Hingga Juni 2020, konvensi regional mengenai crimes related to fisheries ini masih dalam proses perancangan untuk mengakomodasi setiap kepentingan dan tujuan yang hendak dicapai dalam kerjasama regional ini. ${ }^{39}$ Melalui pembentukan kerjasama regional ini diharapkan dapat menekan "Kejahatan Terkait dengan Perikanan" di laut Indonesia dengan mengusut penjahat terorganisir yang berada di negara lain dengan bantuan langsung dari negara peserta konvensi.

\section{Pengaruh Regional Cooperation Agree- ment against Crimes Related to Fisheries terhadap penguatan penegakan hukum maritim di Indonesia}

Konvensi ini ditujukan untuk memenuhi empat hal utama dalam penegakan hukum maritim yaitu penguatan kerjasama internasional, pencegahan "Kejahatan Terkait dengan Perikanan", penegakan hukum secara pidana maupun administratif, serta pengembangan kapasitas bagi aparat penegak hukum negara peserta konvensi.

Kerjasama ini atau instrument regional di masa depan nantinya akan melingkupi penguatan tanggung jawab dari negara bendera kapal (flag states), negara tempat berlabuh (port states), negara berpantai (coastal states), kerjasama antar pelabuhan (port-to-port cooperation), inspeksi kapal penangkap ikan, pertukaran informasi, skema sertifikasi penangkapan ikan, pembangunan kapasitas, kerjasama penegakan hukum, penggunaan asistensi hukum dalam kasus-kasus terkait dengan aktivitas kriminal transnasional. ${ }^{40}$ Substansi penguatan kerjasama internasional nantinya akan mencakup beberapa hal yakni: ${ }^{41}$
a. Bantuan Hukum Timbal Balik (Mutual Legal Assistance);
b. Bantuan Administratif Hukum Timbal Balik (Mutual Legal Administrative Assistance);
c. Kerja Sama Kepabeanan (Customs Cooperation);
d. Ekstradisi (Extradition);
e. Penegakan Hukum dan Kerja Sama Lembaga Penegak Hukum (Law Enforcement and Agencies Cooperation).

Konvensi regional ini pun berniat untuk memiliki komitmen dalam pemenuhan atau pelaksanaan konvensi, pemantauan dan penegakan hukum. ${ }^{42}$ Adapun maksud kerjasama dalam pencegahan "Kejahatan Terkait dengan Perikanan" yakni meliputi: ${ }^{43}$ 
a. Pembagian informasi dan pertukaran Intelijen (Sharing of Information and Exchange of Intelligence);

b. Peningkatan Efektivitas Pemantauan (Raising Awareness Effective Monitoring);

c. Kontrol dan Pengamatan (Control and Surveillance).

Secara garis besar, konvensi ini akan mencakup sanksi yang umum, standar umum yang turut memberikan fleksibilitas bagi negara. Hal ini dikarenakan perlunya kenyamanan bagi negara peserta untuk bisa bergabung dalam konvensi mengingat implementasi tiap negara akan berbeda. Cara pemidanaan atau implementasi ataupun adopsi konvensi tersebut akan diserahkan ke Negara Pihak Konvensi sesuai hak berdaulat masing-masing.

Selanjutnya, kerjasama peningkatan kapasitas aparat penegak hukum atau capacity building juga akan dilakukan meliputi: ${ }^{44}$
a. Kerja Sama Teknis (Technical Cooperation);
b. Pemberlakuan persyaratan khusus bagi negara berkembang (Special Requirement for Developing Parties);
c. Kerja Sama dengan Organisasi Inter- nasional terkait beserta mekanismenya (Cooperation with Relevant Organi- zations and Mechanisms).

Mempertimbangkan empat inti konvensi yang akan dirancang, dapat dianalisa bahwa terdapat beberapa keuntungan yang dapat diraih dengan terlahirnya Regional Cooperation Agreement against Crimes Related to Fisheries. Keuntungan ini dapat diwujudkan dalam beberapa aspek yakni menurut perspektif kemudahan atau percepatan penegakan hukum, penguatan diplomasi Indonesia dan pencegahan meluasnya kejahatan. Tentunya keuntungan ini akan dapat diwujudkan dengan syarat pengimplementasian secara tegas oleh setiap negara anggota konvensi.

Menurut perspektif kemudahan atau percepatan penegakan hukum, salah satu aspek kerja sama internasional di bidang penegakan hukum adalah menangkap pelaku kejahatan. Apabila nantinya "Kejahatan Terkait dengan Perikanan" telah memiliki aturan hukum yang mengikat, maka pelaku "Kejahatan Terkait dengan Perikanan" ini akan lebih mudah untuk ditangkap di negara lain, mengingat semua negara akan wajib untuk tunduk dalam mencegah dan menanggulangi kejahatan tersebut. Selanjutnya, konvensi ini juga ditargetkan untuk mampu memberikan manfaat teknis berupa pertukaran informasi, ahli, serta pemberian anggaran dalam mencegah "Kejahatan Terkait dengan Perikanan" serta mendapatkan pengembangan pelatihan dan kapasitas aparat penegak hukum.

Sedangkan dalam konteks penguatan diplomasi Indonesia, kesuksesan pembentukan Regional Cooperation Agreement against Crimes Related to Fisheries dapat menjadi super diplomacy bagi Indonesia, karena berarti Indonesia berhasil memperjelas maksud sebuah "Kejahatan Terkait dengan Perikanan" dalam rezim crime serta berhasil mengubah persepsi negara-negara yang memiliki pandangan sektor perikanan sebagai rezim manajemen perikanan kini berkembang dalam bentuk Transnational Organized Crime. ${ }^{45}$ Hanya ketika pentingnya interkoneksi ini diterima secara global dan ketika IUUF dan "Kejahatan Terkait dengan Perikanan" dianggap sama seriusnya dengan kejahatan transnasional terorganisir lainnya, maka upaya penegakan hukum akan lebih intens dan mendapat pengawasan internasional. ${ }^{46}$

Tantangan yang ada dalam hubungan

$44 \quad$ Ibid.

45 Galuh Indriana Rarasanti (Staf Fungsional yang bertugas di bagian Direktorat Hukum dan Perjanjian Kewilayahan, Sub Direktorat Kerjasama Kelautan Kementerian Luar Negeri Republik Indonesia) wawancara pada 10 Februari 2018 di Kementerian Luar Negeri Republik Indonesia, Jakarta.

46 Ioannis Chapsos, et al., "Illegal fishing and fisheries crime as a transnational organized crime in Indonesia", Springer, Trends in Organized Crime Vol. 22, No. 3, September 2019, hlm. 271. 
transnasional ialah banyaknya aktor yang terlibat didalamnya. Kondisi ini justru menyediakan peluang. Negara berkembang seperti Indonesia yang memiliki sumber daya alam yang besar, bila dapat dengan tepat memainkan kebijakannya dalam mengenali dan merangkul aktor yang terlibat dalam permasalahan lingkungan hidup akan dapat memaksimalkan keuntungan yang bisa diraih. Banyaknya aktor yang terlibat juga dapat menaikkan posisi tawar negara berkembang bila berhadapan dengan negara maju. ${ }^{47}$

Menurut segi pencegahan meluasnya kejahatan, tak terdefinisinya Transnational Organized Crime $^{48}$ dapat membuka kesempatan perkembangan penetapan kejahatan yang lain untuk masuk dalam Transnational Organized Crime. Kehadiran perjanjian kerjasama ini yang berlandaskan UNTOC sebagai materi dasar dapat memicu negara-negara lain dalam menetapkan kejahatan lain yang semakin berkembang yang nantinya dirasa perlu untuk ditetapkan sebagai Transnational Organized Crime. Penetapan IUUF sebagai Transnational Organized Crime dapat memberikan jalan masuk yang komprehensif bagi dunia untuk memahami masalah lingkungan hidup sebagai bagian dari isu global. ${ }^{49}$

Indonesia harus mampu meyakinkan dan mengajak negara lain untuk mampu bekerjasama dalam menyelesaikan kedua masalah ini terutama terhadap negara tetangga yang memiliki permasalahan serupa seperti Vietnam, China, Thailand, dan Filipina. Konvensi apapun yang akan dicanangkan oleh Indonesia di tingkat internasional maupun regional tidak akan berjalan efektif apabila tidak didukung oleh negara yang memegang peran penting mencegah "Kejahatan Terkait dengan Perikanan" di Indonesia. Dukungan tersebut memerlukan strategi yang tepat sasaran, dan
Indonesia mengupayakan terbentuknya kesamaan kesadaran bahwa sifat dan bentuk kejahatan akan tergantung pula dari yurisdiksi dan penegakan hukum $^{50}$ dari negara tempat pelaku berasal, yang mana pelaku yang hadir tidak berasal dari satu atau dua negara, namun tercakup dalam aktivitas kejahatan lintas negara.

Melalui instrumen mengikat, konvensi ini dapat mengajak negara-negara tetangga untuk sadar tanpa mencari kesalahan masing-masing negara atas pelaku "Kejahatan Terkait dengan Perikanan", namun dengan bekerjasama menangkap oknum yang ada. Pembentukan resolusi dapat dilaksanakan dengan mengajak negara-negara sepenanggungan, tetapi pembentukan konvensi mengenai "Kejahatan Terkait dengan Perikanan" ini dibentuk dalam skala regional dengan bantuan negara pasar untuk mengikat negara target konvensi.

Langkah pembentukan konvensi dapat dilalui dengan 2 (dua) bentuk pendekatan yakni pendekatan kawasan dan pendekatan pasar ikan dunia (Global Fish Market). Pendekatan kawasan dilaksanakan dengan menarget pada negara-negara yang berada dalam satu kawasan regional dengan Indonesia, yakni negara-negara Asia Tenggara dan negara tetangga lainnya seperti Timor Leste, Papua Nugini, Pulau Solomon, Australia, Selandia Baru, Palau, dan China serta negara-negara yang tergabung dalam kawasan regional yang lebih luas daripada itu jika memang memungkinkan.

Pendekatan pasar juga harus dilakukan dengan menarget pada dukungan dan keikutsertaan negara-negara tujuan pasar, seperti Amerika Serikat, Jepang, Uni Eropa, dan Korea dapat berpartisipasi dengan menjadi pihak dalam konvensi ini mengingat Amerika dan Jepang merupakan negara penerima ekspor ikan dari Indonesia.

Negara-negara tersebutlah yang nantinya

\footnotetext{
47 Mahmudin Nur Al-Gozaly, 2009, Diplomasi Indonesia dalam Dinamika Internasional: Perspektif dan Analisis Diplomat Muda Indonesia, Pusat Pendidikan dan Pelatihan Departemen Luar Negeri RI, Jakarta, hlm. 333.

48 John R. Wagley, 2006, Transnational Organized Crime: Principal Threats and U.S. Responses, Federation of American Scientists, CRS Report for Congress, Washington DC.

49 Mahmudin Nur Al-Gozaly, Loc. cit.

50 Jan Glazewski, et al., "Introduction and Overview: Transnational Organised Fisheries Crime", Elsevier: Marine Policy, Vol.105, July 2019, hlm. 121 .
} 
diharapkan menjadi Negara Pihak dalam perjanjian kerjasama ini. Adapun nantinya dasar perjanjian kerjasama ini akan merujuk pada instrumen internasional yang telah ada yakni seperti UNTOC, UNCAT, United Nations Convention Against Illicit Traffic in Narcotic Drugs and Psychotropic Substances, Resolusi Perserikatan Bangsa-Bangsa, serta beberapa referensi lain yang akan menjadi dasar perjanjian. ${ }^{51}$

\section{Langkah-Langkah yang Dapat Dikontri- busikan Indonesia dalam Rangka Men- dorong Terbentuknya Perjanjian Kerja- sama Regional Melawan "Kejahatan Terkait dengan Perikanan" (Regional Cooperation Agreement Against Crimes Related to Fisheries)}

Setiap tahap perancangan perlu dipersiapkan secara detail untuk mengakomodasi setiap kepentingan negara anggota maupun kemudahan pengimplementasian di tahap pelaksanaan. Pada proses pembentukan konvensi, Indonesia dapat mengarusutamakan isu di forum internasional melalui inisiatif peran. Pengarusutamaan isu dapat dilakukan baik dalam skala nasional melalui penguatan legislasi nasional serta pengembangan kapasitas aparat penegak hukum yang terkait.

Pengarusutamaan isu di forum internasional dapat dilalui dengan pembentukan norma yang tidak mengikat dalam bentuk resolusi pada forum perserikatan bangsa-bangsa. Meskipun tidak ada keharusan untuk membuat norma yang tidak mengikat sebelum dibentuknya norma yang mengikat (konvensi), namun pengawalan isu harus terus dilakukan untuk menghindari pasang surutnya isu di kancah internasional. Morale pressure yang mungkin akan didapat ketika resolusi diadopsi oleh banyak negara ialah beberapa negara yang menolak resolusi ini, tentunya akan turut mempertaruhkan reputasi di dunia internasional.

Indonesia dapat memanfaatkan forumforum internasional lainnya untuk terlibat dan menunjukkan keseriusan Indonesia dalam melawan "Kejahatan Terkait dengan Perikanan". Indonesia dapat bergabung pada kampanye-kampanye yang dilahirkan dalam rangka melawan "Kejahatan Terkait dengan Perikanan" oleh organisasi internasional berupa kontribusi dalam simposium, dan working group seperti FishCRIME symposium pada Oktober 2016 di Yogyakarta. ${ }^{52}$

Kontribusi lain yang dapat dilakukan Indonesia dalam mengarusutamakan isu ini ialah melalui narasi tunggal. Narasi tunggal dari Indonesia adalah hal yang penting dalam rangka menyamakan persepsi terutama dalam pemakaian istilah yang akan digunakan nantinya dalam mengupayakan "Kejahatan Terkait dengan Perikanan". Penyamaan istilah secara internasional dapat menjadi ide diskusi pada forum-forum internasional yang tepat, mengingat masih banyaknya keberagaman istilah yang digunakan baik di nasional sendiri dan internasional.

Berdasarkan sisi hukum nasional pun, pemerintah harus mulai mempertimbangkan pembaharuan hukum nasional mengenai "Kejahatan Terkait dengan Perikanan" sebagai bentuk 'multi crimes' (terminologi yang digunakan Norwegia) dengan sanksi pidana yang lebih tegas. Hal ini dikarenakan 'multi crimes' tersebut hadir dengan berbagai macam kemungkinan pelanggaran kriminal dalam sektor perikanan $^{53}$ baik terorganisasi maupun tidak terorganisasi. Negara lain seperti Rusia dan China sudah mulai untuk mengidentifikasi bahwa IUUF yang digerakkan oleh kelompok penjahat terorganisasi dapat pula memenuhi syarat untuk dimasukkan dalam bentuk 'serious crime'. Meskipun dalam hukum nasional Rusia dan China pun belum terlalu rinci

\footnotetext{
51 Indra Rosandry (Kepala Sub Direktorat Hukum dan Perjanjian Politik dan Keamanan, Direktorat Jenderal Hukum dan Perjanjian Internasional Kementerian Luar Negeri Republik Indonesia) wawancara pada 12 April 2018 di Kementerian Luar Negeri Republik Indonesia, Jakarta.

52 Jan Glazewski, et al., "Introduction and overview: Transnational organised fisheries crime", Elsevier: Marine Policy, Vol. 105, July 2019, hlm. 118.

53 Ibid.
} 
dalam menjabarkan aktivitas kriminal dari IUUF. ${ }^{54}$ Amerika Serikat pun merupakan salah satu negara yang telah mengidentifikasi penjualan tangkapan hasil IUUF berpotensi sebagai 'serious crime'. ${ }^{55}$

Langkah pembaharuan hukum ini dapat menjadi bukti kemantapan niat Indonesia dalam menyadari pentingnya penegakan hukum "Kejahatan Terkait dengan Perikanan" dalam kaitannya dengan Transnational Organized Crime. Indonesia harus siap dan mampu memperlakukan pelaku kejahatan dengan sanksi pidana yang lebih tegas.

\section{Kesimpulan}

Kehadiran perjanjian kerjasama ini diharapkan untuk mampu memberantas "Kejahatan Terkait dengan Perikanan" yang tidak terbatas pada lingkup IUUF namun kejahatan lain yang mungkin terikat dalam rantai kejahatan transnasional dan terorganisasi dalam skala regional. Sulitnya pemberantasan kejahatan hingga ke akar diharapkan mampu diatasi dengan kerjasama penegakan hukum antara Indonesia dengan negara kawasan regional Asia Tenggara serta pasar ikan dunia untuk mengusut para penjahat transnasional yang menjalankan praktik "Kejahatan Terkait dengan Perikanan".

Mengingat proses pengkualifikasian "Kejahatan Terkait dengan Perikanan" dalam bentuk Transnational Organized Crime secara spesifik masih menjadi beban internasional melalui organisasi internasional, setidaknya Indonesia dapat berusaha memperkuat penegakan hukum di kawasan regional. Perjanjian kerjasama ini dirancang guna memperkuat kerjasama internasional dalam pencegahan "Kejahatan Terkait dengan Perikanan", penegakan hukum secara pidana maupun administratif, serta pengembangan kapasitas bagi aparat penegak hukum negara anggota. Melalui rancangan perjanjian kerjasama regional ini, setidaknya negara-negara kawasan regional mendapatkan kemudahan investigasi dan penegakan hukum, memperkuat diplomasi Indonesia serta mencegah meluasnya kejahatan terkait. Tentunya keuntungan ini dapat diwujudkan dengan syarat pengimplementasian secara tegas oleh setiap negara anggota konvensi.

Proses perancangan perjanjian kerjasama dapat terus didukung dan didorong melalui kontribusi Indonesia dengan pengarusutamaan isu di forum internasional. Terwujud dalam pengupayaan pembentukan norma tidak mengikat atau resolusi pada forum Perserikatan BangsaBangsa, keterlibatan Indonesia dalam kampanye dan narasi tunggal penegakan "Kejahatan Terkait dengan Perikanan" di level internasional, serta pembaharuan hukum nasional sebagai wujud keseriusan Indonesia dalam memberantas serta mencegah "Kejahatan Terkait dengan Perikanan".

\section{DAFTAR PUSTAKA}

\section{A. Buku}

INTERPOL Global Fisheries Enforcement, 2018, International Law Enforcement Cooperation in the Fisheries Sector: A Guide for Law Enforcement Practitioners, INTERPOL, Lyon.
Marzuki, Peter Mahmud, 2008, Penelitian Hukum, Kencana, Jakarta.

Ng, Ada Suk Fung, 2011, A Maritime Security Framework For Fighting Piracy, Institute Of Transport and Logistics Studies, Working Paper ITLS-WP-11-21, The Australian

\footnotetext{
54 Anastasia Telesetsky, "Laundering Fish in the Global Undercurrents: Illegal, Unreported, and Unregulated Fishing and Transnational Organized Crime”, Ecology Law Quarterly, Vol. 41, No. 4, hlm. 980.

55 Ibid.
} 
Key Centre in Transport and Logistics Management, The University Of Sydney, Australia.

Al-Gozaly, Mahmudin Nur, 2009, Diplomasi Indonesia Dalam Dinamika Internasional: Perspektif dan Analisis Diplomat Muda Indonesia, Pusat Pendidikan dan Pelatihan Departemen Luar Negeri RI, Jakarta.

Sutopo, Ariesto Hadi, et al., 2010, Terampil Mengolah Data Kualitatif dengan NVIVO, Prenada Media Group, Jakarta.

Wagley, John R., 2006, Transnational Organized Crime: Principal Threats and U.S. Responses, Federation of American Scientists, CRS Report for Congress, Washington DC.

\section{B. Artikel Jurnal}

Boister, Neil, "The Cooperation Provisions of the UN Convention against Transnational Organised Crime: A Toolbox Rarely Used," International Criminal Law Review, Vol. 16, No. 1, Februari 2016.

Chapsos, Ioannis, Steve Hamilton, "Illegal Fishing and Fisheries Crime As A Transnational Organized Crime in Indonesia", Springer, Trends in Organized Crime Vol. 22 No. 3, September 2019.

Glazewski, Jan, "Legal and Practical Challenges Around Restitution, Secrecy and Asset Recovery in Transnational Fisheries Crime: A Case Study of United States v Bengis, 2013", Elsevier: Marine Policy, Vol.105, July 2019.

Liddick, Don, "The Dimensions of A Transnational Crime Problem: The Case of IUU Fishing", Springer, Vol. 17, No.4, Desember 2014.

Muhamad, Simela Victor, "Illegal Fishing di Perairan Indonesia: Permasalahan Dan Upaya Penanganannya Secara Bilateral Di Kawasan", Jurnal Politica, Vol. 3, No. 1, Mei 2012.

Ningsih, Sri Dewi R., et al., "Corporation as The Actors of Fisheries Crime in Indonesia", Jurnal Dinamika Hukum, Vol. 18, No.2, May
2018.

Raymond, Catherine Zara, "Piracy and Armed Robbery in The Malacca Strait", Naval War College Review, Vol. 62, No. 3, Summer 2009.

Stølsvik, Gunnar, "The Development of The Fisheries Crime Concept and Processes To Address It in The International Arena", Elsevier: Marine Policy, Vol. 105, Juli 2016. Stringer, Christina, et al., "Human Trafficking As A Fisheries Crime? An Application of The Concept To The New Zealand Context", Elsevier: Marine Policy, Vol. 105, Juli 2019. Telesetsky, Anastasia, "Laundering Fish in the Global Undercurrents: Illegal, Unreported, and Unregulated Fishing and Transnational Organized Crime", Ecology Law Quarterly, Vol. 41, No. 4.

Yuliantiningsih, Aryuni, et al., "From Illegal, Unreported and Unregulated Fishing to Transnational Organised Crime in Fishery from an Indonesian Perspective", Journal of East Asia and International Law, Vol.11 No. 2, November 2018.

\section{Makalah atau Pidato}

Direktorat Hukum dan Perjanjian Politik dan Keamanan Kementerian Luar Negeri. 2017. Bahan Paparan Direktur Jenderal Hukum dan Perjanjian Internasional Kementerian Luar Negeri "Evaluasi Nawacita Pemerintahan Jokowi di Bidang Kerja Sama Maritim" Aspek Illegal, Unreported, and Unregulated Fishing (IUUF) dan Kejahatan Transnasional Terorganisasi di Sektor Perikanan. Jakarta: Kementerian Luar Negeri.

\section{Internet}

BBC Indonesia, “Sidang kasus 'perbudakan' di Benjina digelar", http://www.bbc.com/indonesia/berita_indonesia/2015/11/151118_ indonesia_benjina_tual, diakses 3 Desember 2017. 
CNBC Indonesia, "Susi Akui RI Pernah Rugi Rp 2000 T Akibat Illegal Fishing", https://www. cnbcindonesia.com/news/201806260758224-20458/susi-akui-ri-pernah-rugi-rp-2000-takibat-illegal-fishing, diakses Juni 2018.

Maulana, Hadi, "1 Ton Sabu Disita dari Kapal Berbendera Singapura, Nilainya Capai Rp 1,5 T", https://regional.kompas.com/ read/2018/02/10/07120901/1-ton-sabudisita-dari-kapal-berbendera-singapuranilainya-capai-rp-15-t, diakses 7 Maret 2018.

Sari, Elisa Valenta, CNN Indonesia, "Benjina, Kisah Perbudakan Ratusan Nelayan di Timur Indonesia”, $\quad$ https://www.cnnindonesia. com/ekonomi/2015040 7155215-92-44823/ benjina-kisah-perbudakan-ratusan-nelayandi-timur-indonesia/, diakses 3 Desember 2017.

United Nations, "Indonesia Leads the Establishment of a Regional Cooperation to Combat Crimes in Fisheries Sector by Indonesia, Coordinating Ministry for Maritime Affairs of the Republic of Indonesia \#OceanAction 1512", https://oceanconference.un.org/ commitments/?id=15127\#updates, diakses 18 Juni 2020.

\section{E. Peraturan Perundang-undangan}

Peraturan Presiden Nomor 16 Tahun 2017 tentang Kebijakan Kelautan Indonesia (Lembaran Negara Republik Indonesia Tahun 2017 Nomor 32).

Undang-Undang Republik Indonesia Nomor 45 Tahun 2009 Tentang Perubahan Atas Undang-Undang Nomor 31 Tahun 2004 Tentang Perikanan (Lembaran Negara Republik Indonesia Tahun 2009 Nomor 154, Tambahan Lembaran Negara Republik Indonesia Nomor 5073).

\section{F. Dokumen Resmi Lain}

United Nations Convention Against Transnational Organized Crime, 2004, United Nations: New York.

United Nations Convention on the Law of the Sea 1982 United Nations, Resolusi Majelis Umum Perserikatan Bangsa-Bangsa A/ RES/70/1, 21 Oktober 2015. 